\title{
The Cinema of Darrell James Roodt
}

\author{
By Martin P. Botha \\ Spring 2013 Issue of KINEMA
}

\section{THE JOURNEYS OF THE MARGINALISED: THE CINEMA OF DARRELL JAMES ROODT}

South African director Darrell James Roodt is one of the most dominant and prolific figures in the South African film industry (Armes 2008: 112), having made a total number of 34 feature films and several television series to date. Surprisingly, few academics have devoted chapters in books or doctorate dissertations to his work (Blignaut ES Botha 1992; Botha \&J Van Aswegen 1992; Murphy ES Williams 2007; Treffry-Goatley 2010). Roodt's oeuvre includes some of the milestones in South African cinema since 1980s, as well as genre films such as Dracula 3000 (2004) which received negative notices by critics (Murphy 63 Williams 2007).

This article forms part of an ongoing investigation into the cinema of Roodt and is a follow-up to an earlier attempt to explore some of the major themes in his oeuvre (Botha 2011).

Darrell Roodt was born in Johannesburg in 1962 and attended the King Edward School. He enrolled at the University of the Witwatersrand to study drama, but left after one week to make films.

\section{Early Roodt and his gallery of characters at the margin of apartheid society}

Roodt's A Place of Weeping (1986), made at the age of 23, was produced and marketed internationally by Anant Singh, who became one of South Africa's most prominent film producers. The film deals with racial conflict. A black farm worker is beaten to death by his employer after complaining about his poor wages. The murder goes unreported since the other labourers fear for their future. A news reporter, however, becomes involved when a housemaid on the farm attempts to report the incident. Although seriously flawed due to poor performances from the actors, the film featured striking cinematography by Paul Witte. Notably the film also features a strong black woman living at the margin of apartheid society and her struggle against social injustice, a theme which would become a strong motif in Roodt's oeuvre during the 1980s, 1990s and 2000s.

Roodt's The Stick (1987) was the first South African film to examine the deployment of South African troops in cross-border raids during the South African Border War. The war is also commonly referred to as the Angolan Bush War in South Africa and is also known as the Namibian War of Independence. It refers to the conflict that took place from 1966 to 1989 in South-West Africa (now Namibia) and Angola, between South Africa and its allied forces (National Union for the Total Independence of Angola, UNITA) on the one side and the Angolan government, South-West Africa People's Organization (SWAPO), and their allies - mainly the Soviet Union and Cuba - on the other. It was closely intertwined with the Angolan Civil War.

The film begins with an introductory sequence filmed in one long take in black and white: One of the white heroes of the film (Greg Latter) is shown in his school uniform and his voice over on the soundtrack states: "My father sent me to war to make a man of me. He was wrong". The character is part of a "stick" of men. Seven soldiers and a black tracker enter presumably Angola on a mission to exterminate a traditional healer, whose advice to rebel forces is regarded as destructive to South African security force efforts. Roodt's personal vision of the South African border war between South Africa and SWAPO is one that is linked to the genre of the American war film of the 1970s and 1980s, films praised for their critical examination of the psychological scars left on soldiers by the Vietnam War. These films (for example, The Deer Hunter, Apocalypse Now, Platoon and Born on the fourth of July) are characterised by their graphic, detailed depiction of war. Roodt's film is no exception in this. By portraying war vividly and emphasising fear and confusion through the use of first-person narration on the soundtrack Roodt aligns himself with the anti-war genre (Botha \& Van Aswegen 1992).

What fascinates Roodt is the physical and mental disintegration of the white protagonists after they have destroyed African lifestyles by wiping out a village of women and children, as well as the traditional healer. The violence is directed at characters living at the margin, powerless to defend themselves against the 
military brutality. The film becomes a surreal and nihilistic work; that which is incomprehensible to the white protagonists, namely Africa, is portrayed as sinister and irrational. The soldiers are clearly not equipped to combat this "supernatural" force. The film becomes an allegory of South Africa's political and military failure in Angola and Namibia to defeat SWAPO and the Ovambo population. This sentiment is made clear by the young hero's words to a senior military officer at the end of the film. When the soldier returns to South Africa he is confronted by the traditional healer in the shape of an ordinary black man. In other words, Africa still surrounds him - he cannot destroy it. To fight against it means self-destruction.

The film was initially banned in South Africa and the ban was upheld through various applications for screenings at film festivals until it was finally allowed to be screened at the Weekly Mail Film festival in 1989. The censors ordered 48 cuts before they would consider re-appraising the film (Ozynski 1989).

Stylistically The Stick is a remarkable film and forms part of auteur Roodt's trilogy on racial conflict in a rural milieu (A Place of Weeping, The Stick and Jobman). In the rural "wastelands" of animal carcasses (The Stick) or wrecked cars (Jobman), over which the camera of Paul Witte slowly pans in long takes from left to right, Roodt envisages a disintegrating white middle-class (magnificently conveyed in the party scene in Jobman). The pastoral Eden of the earlier Afrikaans cinema of the 1970s (see Botha 2012) has given way to an inhospitable symbolic "wasteland" in which people eventually would die (for example the final shootout in Jobman or battle in The Stick). David Barkham's art direction contributes significantly to the representation of this wasteland. The landscapes, which are sometimes characterised by wrecked cars, are a motif in Roodt's films of the 2000s.

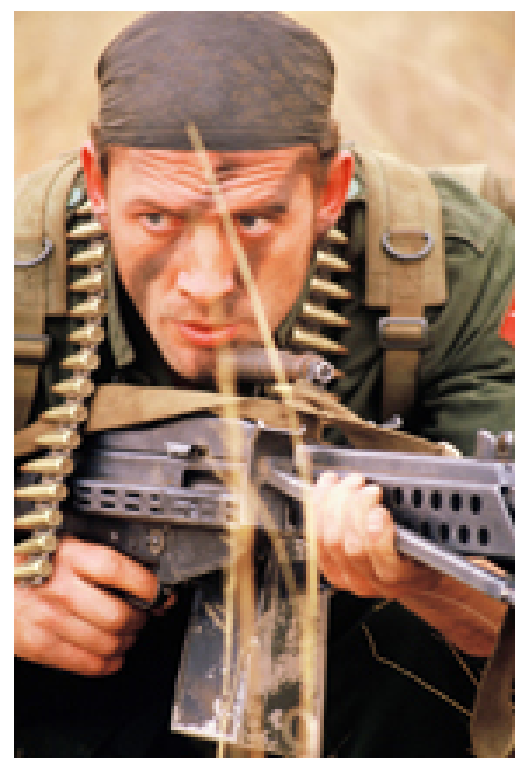

Figure 1: Gys de Villiers in The Stick by Darrell James Roodt

Roodt's Sarafina! (1992) based on Mbongeni Ngema's stage musical about the school boycotts of 1976 and their brutal suppression by the police, resulted in international recognition for the director. It received a ten-minute standing ovation at the 1992 Cannes Film festival where it was shown in the official selection. It stars Whoopi Goldberg, Leleti Khumalo and Miriam Makeba. The film once again features strong women, who demonstrate some form of resistance against social injustice (Murphy \& Williams 2007). Sarafina! also characterises Roodt's use of genre (the musical) in combination with strong socio-political content (the Soweto youth uprising of 1976). Jobman (1989) is a western, which features a marginalised character in South African society of the early 1960s. The Stick fits into the Vietnam War genre, but also explores South Africa's military involvement in Angola and Namibia. It was thus no surprise that Roodt would also explore the period drama. In the early 1990s Ronald Harwood adapted Alan Paton's novel Cry the Beloved Country for Roodt and producer Anant Singh.

Set in the 1940s it follows the journey of a Zulu pastor, Stephen Kumalo (James Earl Jones), from rural 
Zululand to Johannesburg to look for his son. Kumalo's journey brings him into direct conflict with a white man, James Jarvis (Richard Harris), who has lost his son in a violent crime. Through various tragic events, both men are forced to learn the lesson of forgiveness with dignity, a theme relevant to post-apartheid cinema. Visually the film is exquisite and John Barry's musical score enhances the deep-felt sadness of the events in the film. Anant Singh has been an important partner for Roodt over the years. They met as anti-apartheid filmmakers, felt a connection, and have been making films together ever since (Treffry-Goatley 2010). Singh has worked as a producer on many of these films, and the distribution arm of his company, Videovision, has also been responsible for certain international and local sales. Videovision, as the production company for many of these films, has also been an important source of finance for Roodt, who noted on the director's commentary for Yesterday (2004) that he is very lucky to have Singh's support because he has sometimes financed entire productions such as Faith's Corner (2005).

Although Roodt has made many politically and socially conscious films, he has also shot numerous genre orientated films for the foreign market. These include Blood City (1987), To The Death (1991), Father Hood (1993), The Second Skin (2000), Pavement (2002), Dracula 3000 (2003) and Prey (2007) and are not part of the focus of the article.

Of crucial concern in my discussion about characters on the margin of South African society is an earlier landmark by Roodt. In Jobman (1989) the protagonist is a 25-year old deaf and mute "coloured" man (Kevin Smith), who has been messed around and misunderstood all his life. When the film opens he is in Kimberley. The setting is Christmas 1960. Jobman is picked up by the police and stripped of his humanity. A parallel story moves the setting to a Karoo farm, where Jobman was born. The farmer dies and the farm is reluctantly inherited by his son, Karel (Tertius Meintjies in an award-winning performance). Jobman return to the farm to fetch his wife and child, but is rejected by his own community as a social outcast. He also provokes fear in the white community. The only person who sides with him is the young farmer. As the situation finally ends in violence, a confrontation arises between the man and his former friend. Roodt's film vividly analyses the tragic paradox and practice of Christian brotherly love during the first years of the Verwoerdian regime. The images depict a disintegrating white middle-class trapped in its laager in an arid landscape strewn with wrecked cars and the carcasses of animals. David Barkman's art direction is excellent. The film was the last one shot by Paul Witte, who was tragically killed in a car accident in 1990. Jobman begins with a quote from Bertolt Brecht: "Pity the nation which has no heroes. No. Pity the nation which needs heroes". Within the context of Jobman the statement is ironic since the main character has been born without a tongue and can't speak.

These independently made features form part of a broad focus in post-apartheid cinema on people living on the periphery of society. Since 1994 South African audiences have been exposed to certain marginalised communities, such as the homeless in Francois Verster's remarkable documentary Pavement Aristocrats: The Bergies of Cape Town (1998), the Himbas of Kaokoland in Craig Matthew's Ochre and Water: Himba Chronicles from the Land of Kaoko (2001), AIDS victims in Shouting Silent (2001), the gay subcultures of the fifties and sixties in The Man Who Drove With Mandela (1998), street children in Hillbrow Kids (1999), prison inmates in Cliff Bestall's Cage of Dreams (2000) and the San in the Foster Brothers' visual poem The Great Dance (1999). The latter has already won more than 35 international and national awards, the most for a single film in the history of South African cinema. Wynand Dreyer's trilogy of documentaries about ordinary lives on the Cape Flats, Ravensmead, A Piece of Life, A Piece of Death and Steel upon Steel is a lyrical and moving document.

The term 'marginality' will be used in this article to describe the economic and social conditions of individuals within a society, social classes within a nation, or nations within the larger world community. Here it also refers to poverty-stricken groups left behind in the modernization process. They are not integrated into the socio-economic system and their relative poverty increases.

Marginalised communities feature strongly in recent South African cinema after a silence of more than 90 years due to colonialism and apartheid (Botha 2012). Of major importance in this regard is the cinema of Roodt (Sarafina!, Yesterday). Roodt's recent films (Yesterday, Faith's Corner, Meisie, Lullaby, Little One, Zimbabwe) have all explored marginalised female characters. A major motif in almost all these films, including Jobman, is the representation of the attempts by the characters to survive. A major part of the 
depiction of the marginalised characters' struggle is the emphasis on the physical journey. A journey is the act of travelling from a departure point to a destination. Physical journeys in particular encompass this fundamental process; however, the physical journey is much more than that. It is a combination of the physical movement and the challenges and obstacles which confront the traveller emotionally and spiritually. Images of homeless characters walking for kilometres through barren rural landscapes or decaying urban environments dominate Roodt's cinema of the 2000s.

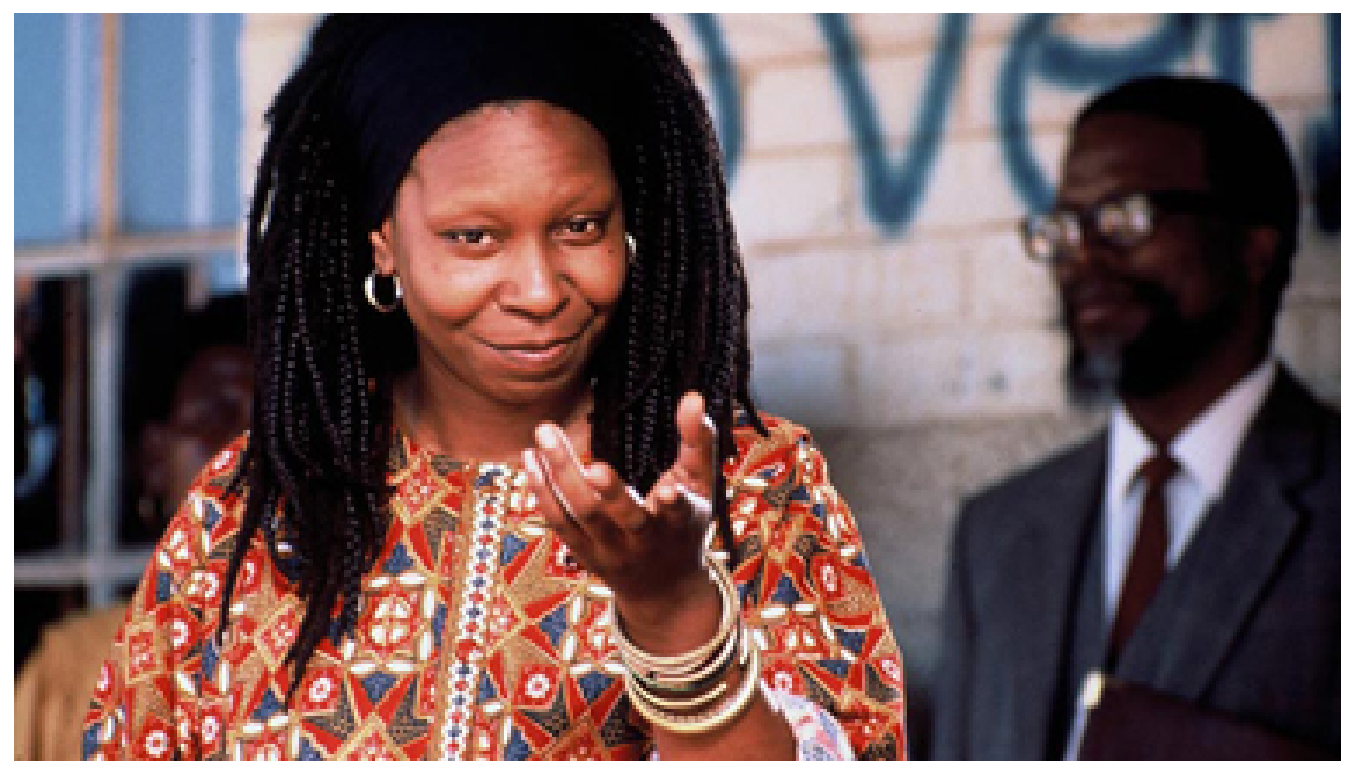

Figure 2: Whoopi Goldberg in Sarafina! by Darrell James Roodt

\section{The journeys of the marginalised}

Zimbabwe (2008) opens with an overwhelming sense of the rural landscapes - a strong feature in Roodt's other work (Yesterday, Meisie, Cry the Beloved Country, Jobman). The gaze is observational and the narrative structure almost impressionistic. Without any dialogue the viewer witnesses a burial. Scenes of attempts to survive in a harsh rural environment follow. Zimbabwe, the main protagonist, is an orphan. Her parents and sister have died of AIDS. The members of her community are not able to look after her and she is forced to travel to a family member in Beitbridge, a town on the border with South Africa, for support. Roodt brilliantly integrates the rural landscapes with the socio-political realities of the characters without explicitly commenting on the politics of Robert Mugabe's Zimbabwe. He accentuates the physical challenges of Zimbabwe's journey to an urban area. Gradually the pastoral images are replaced by an urban landscape, which is characterised by social decay. Zimbabwe's family member is an alcoholic and she lives in difficult circumstances. The surrounding landscape is marked by wrecked cars as in the case of Jobman.

Zimbabwe's situation worsens when she is forced to work as an illegal domestic worker in Johannesburg, where she is exploited by both the agency, which is supposed to act on her behalf, a well as by her white male employer, who rapes her on several occasions. Her name is changed to Miriam and she is not allowed to display her identity as a Zimbabwean due to xenophobia and her illegal status in South Africa. Roodt's examination of the exploitation of Zimbabwean citizens in South Africa is brutal and moving. In the end Zimbabwe is forced to return to her homeland and an uncertain future.

Jobman's journey is more tragic. The film's opening long shot frames him in a dust road, walking through the barren landscape of the Karoo, a semi-desert in South Africa. He wears no shoes. The next sequence depicts his birth in 1933. His mother dies during the process and the child has no tongue and thus no voice. In the next sequence Jobman is now a young adult.

It is 1960, the height of apartheid under Prime Minister Hendrik Verwoerd. The country was experiencing a stormy socio-political era. The large-scale opposition to apartheid legislation took on tragic dimensions on 21 March 1960 when at Sharpeville 69 people were shot dead, many in their backs, and 180 were wounded. A 
state of emergency was declared and over 11,500 people were detained. On 8 April 1960 the African National Congress (ANC) was proclaimed a legally banned organisation. White racism is rife. Several young white men confront Jobman and demand that he speaks to the white "bosses". His inability to communicate is perceived as being defiant and he is severely beaten. On the wall behind him are posters with the caption: Vir Volk en Vaderland (For the nation and the homeland).

While he is lying in a pool of blood, homeless people strip him and take his clothes. He is discovered by the police. At the station the doctor confirms that he is not able to speak and that he should go to a hospital for the treatment of his head injuries. Instead, the white police drop him at an industrial site and shoot warning shots at him. He runs away, half naked. Due to Jobman's lack of speech it is difficult to obtain a nuanced understanding of him as a character, as well as what motivate his actions. A full back story also doesn't exist. We learn later as viewers he was a troublemaker on the farm where he was born and that Karel and he were childhood friends. His decision to return to the farm and be reunited with his wife, Anna, and his child, lacks clear motivation. As a mute, marginalised character, does Jobman represent the voiceless black majority of the apartheid state during the 1960s? It is difficult to arrive at such an ideological reading.

Roodt vividly emphasized the challenging nature of Jobman's physical journeys. He walks endlessly without shoes along a dirt road or railway line. These shots will be repeated in many of Roodt's work of the 2000s. The houses of the farm workers are within a few hundred metres from wrecked cars. Jobman, Anna and the baby try to make a living in an old church, but Karel requests them to leave his farm. Karel destroys the church and once again Jobman and his family are wandering through the barren Karoo landscapes - homeless, hungry, without shelter. A confrontation with the police results in a bloodbath and Jobman becomes an outcast and like a character in a Western, a wanted man. Sadly, despite the visual poetry of the film, Roodt allows the narrative at this stage to develop into a conventional Western with the final confrontation between Jobman and Karel at a train station. Whereas several characters in Roodt's subsequent films will transcend their marginal status, Jobman dies a voiceless victim.

Roodt's internationally acclaimed film Yesterday (2004) is one of the studies of characters on the margin of South African society where the main protagonist transcends her marginal status towards the end of the narrative. It tells the story of a young black woman with AIDS. Within the temporal frame of the story, which is barely a year, Yesterday's life undergoes radical change. Physically, socially and existentially, her fortunes are profoundly altered when she becomes ill (Horne 2005). The significance of time is also seen in the importance of history in Yesterday's experience. There is considerable irony in Yesterday's father's belief that the world of yesterday was better than the world of the present, since the tragic turn his daughter's life takes is directly linked to events in the past. The importance of time also features in the chronological structure of the narrative which is explicitly marked by the naming of the seasons as these pass. This sequencing device creates a sense of the relentlessness of the passage of time and the inexorability of death. Roodt brilliantly depicts a socio-political milieu characterised by rural poverty, an inadequate primary health care system, a lack of a support base, community stigmatisation, domestic violence, a lack of formal education, as well as a lack of empowerment (Horne 2005; Treffry-Goatley 2010).

Significantly however, the film is about the main character's growing sense of empowerment, not her misery. Although she is representative of nameless millions with no status in the social hierarchy of South Africa, Roodt inverts the social order, unlike in Jobman, adopting the discourse of transformation during the duration of the film (Horne 2005; Treffry-Goatley 2010). His achievement, as in the case of Meisie (2007), is the representation of a character, which ultimately transcends her marginal status.

The long opening shot of Yesterday establishes the time-frame, setting and crucial thematic elements of the narrative. In a way it resembles the opening shot of Jobman and the viewer's first impression of the main protagonist. It is a long take of a vast, empty, rural landscape - an area in KwaZulu-Natal. The environment is barren. As the camera slowly tracks, a dirt road slowly comes into view and along this we see two tiny figures walking towards the camera, "their smallness in the vast space around them suggesting their insignificance" (Horne 2005: 173).

They remain indistinct for some time because of the distance, dust and heat haze. The take continues for more than four minutes uninterrupted as the two people slowly become visible. The duration of this long take indicates the length of their journey and the unhurried pace of life. "Only after several minutes, during 


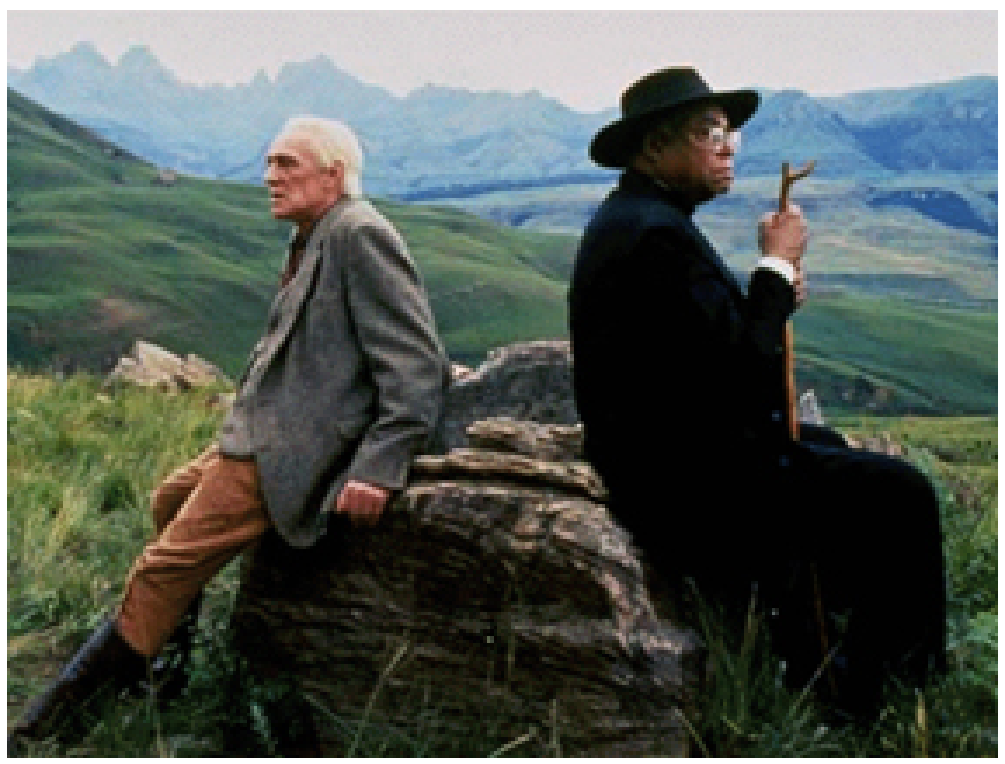

Figure 3: Richard Harris (1.) and James Earl Jones in Cry the Beloved Country

which time the audience is left to wonder who these obscure individuals are, where they come from, and where they are going, do they become recognisable as a black woman and a child - the main protagonist, Yesterday, and her daughter, Beauty. As their IsiZulu dialogue becomes audible, we hear the child asking why they cannot fly like birds: she is clearly tired of walking. The mother's patient and good-humoured answers indicate a close and loving bond. The dialogue calls attention to how poor they are: travelling by motorised transport seems as much of a possibility as flying" (Horne 2005: 137). This remarkable sequence forms part of a type of iconography in Roodt's cinema about physical journeys by characters on the margin of society.

On several occasions Roodt accentuates Yesterday's challenging physical journeys to get medical assistance only to be turned away to come back the next week since the rural clinic can't cope with the numbers of patients. The filmic device of repetition, where Roodt shows her going through the same futile process week after week, builds concern for her as well as an awareness of the inadequacy of the health services available to her (Horne 2005). Highlighted in her encounter with a doctor is Yesterday's lack of education, as in the case of Faith in Faith's Corner (2005). Following the doctor's instructions to inform her husband, John Khumalo, of her HIV status, so that he can be tested himself, Yesterday makes another difficult journey - this time to the mines of Johannesburg. As in the case of Zimbabwe and Faith's Corner the viewer observes the urban landscape through the eyes of the female protagonists as the camera shows the intertwined shadows of the urban crowds on the pavement and the skyscrapers filmed from low, oblique angles, accentuating their height and making their shapes seem grotesque. The tilted camera angles have a confusing, destabilising effect so that we experience the urban jungle from Yesterday, Faith and Zimbabwe's perspectives as an alien, intimidating and threatening place.

Yesterday's encounter with her husband is one of the most disturbing moments in the film. There is some stilted dialogue between them before the scene cuts to the interior of a room where the viewer sees but cannot clearly hear them speak: We as observers are left to imagine the conversation that takes place. Visually, their figures are vague as the encounter is shot from the window of the adjacent office where the same mine official sits reading the newspaper, his back to the window. When the tall silhouette in the room behind him lunges forward and strikes the smaller one and we hear Yesterday's faint screams, the mine official turns around and observes what is happening, but dismisses the sight with a regretful, fatalistic shake of the head. He does not intervene. The focus remains on him in the foreground while the husband's actions of repeatedly punching Yesterday's cowering body are kept in the background. The camera's physical distance from the action conveys the official's (and society's) emotional detachment. The background goes more and more out 
of focus so that it becomes increasingly blurred and shadowy, and Yesterday's screams become inaudible, suggesting how successfully the official shuts the assault out of his consciousness (Horne 2005).

When Yesterday's husband returns to the village in Kwazulu-Natal, his fragile frame indicates that he is suffering from full-blown AIDS. Instead of being resentful Yesterday treats him with compassion. She is unsuccessful to get him into hospital due to fact that there are just too many patients. Yesterday's strange plan of building her own 'hospital' for the husband some distance from the village is an indication of the desperation to which she is driven because of the lack of space at the hospital and the villagers' hostile attitude towards her and her husband as AIDS sufferers. He is regarded with a mixture of suspicion and aggression by the other villagers, who, having guessed that he has AIDS, are eager to expel him from their midst, perceiving him as polluting (Horne 2005).

It is an important moment in the narrative since Yesterday is taking control of her situation. Her psychological strength is even more impressive than her physical endurance. Displaying independence, resourcefulness and courage, Yesterday shows that she has assumed complete power over her situation. Her actions show her refusal to live fearfully and be at the mercy of the villagers' intolerance. In the absence of outside help, she finds her own solution, imperfect though this is. In a dramatic reversal of their original roles, her husband ends his days totally dependent on her (Horne 2005). In the end she assists him to pass on and she manages to stay alive till her daughter goes to school. In a parallel of the opening scene, the film's closing take shows Yesterday's figure making its way slowly along the deserted dirt road winding into the distance. This time, however, she is alone, dressed in black and walking away from - rather than towards - the viewer. The differences are subtle but powerful signifiers of imminent death. "Her metaphorical journey transcends the mundane and takes on an epic quality, elevating the meaning of her life and suffering" (Horne 2005: 182).

Yesterday remains an important, progressive addition to the post-apartheid cinematic repertoire. Furthermore, Roodt's application of certain neorealist elements in the film might also be seen as a breakthrough in an industry where the pervasive influence of Hollywood is evident not only in the distribution, exhibition and consumption practices of the country, but also in the widespread application of the classical narrative conventions in cinematic production (Treffry-Goatley 2010).

The physical journey is also a strong feature in Faith's Corner (2005). The film follows the life of Faith, a homeless beggar and a single mother of two young sons, Siyabonga and Lucky. They live in an abandoned car in an alleyway of central Johannesburg. Faith spends her days begging for money from disinterested commuters on the streets. Darrell Roodt's experimentation with film form is remarkable: Shot in the style of the silent cinema, complete with intertitles to capture the dialogue, the film sensitively confronts social issues of poverty and joblessness in South Africa. It is a vivid combination of social concern and formal experimentation. By using the silent format it almost makes a statement that social conditions for the poor haven't changed over the decades.

The rural landscape of Yesterday is now only a memory in a story Faith conveys to her children. The only signifiers of the farm are the noises of animals on the soundtrack while Faith and her children are sitting outside the abandoned car in a filthy alley in Johannesburg. The wrecked cars in the rural landscapes of Jobman, Zimbabwe and Yesterday are now the homes for the homeless. When the car is not available anymore the family seek shelter in a graveyard. Roodt depicts within repetitive sequences Faith's desperate attempts to beg money from passing motorists at a busy street junction. The viewer seldom sees the drivers - mostly only Faith's reflection in the windows of the cars. With the little money she makes Faith tries to raise her children, though they often go to sleep hungry. Faith deals with the apathy of the motorists that pass her, but also the distrust and anger of other homeless souls on the streets of Johannesburg. Most of the narrative consists of a brilliant representation of survival on the streets and the physical journeys of the characters to get money, food, shelter or in one sequence Faith carrying her sick child to hospital. Images of Faith and her children working in the streets of the city are a haunting memory of Roodt's finest film to date.

Yesterday and Zimbabwe, as well as Meisie (Girl), a multi award-winning film, focus on poverty in rural South Africa. Meisie is a slice of life about a girl in a rural community who is prevented from going to school by her father who believes that she should spend her days tending goats instead. Shot in the style of neorealism the film features wonderful natural performances by non-professional actors from the remote community of Riemvasmaak, on the edge of the Kalahari. The landscapes resemble the barren landscapes in 
Jobman. The impressionistic narrative structure consists of glimpses of life in this semi-desert environment. Meisie lives in a shack with her dad in the mountain, about 15 kilometres from the small town and the school. The plot deals with the attempts by the new teacher, Esmeralda September, to convince Meisie's father to allow her to attend school. Her attempts include several physical journeys to Meisie's home and a spot underneath a tree, which serves as a school. It is a journey of 15 kilometres by foot - and once again Roodt visually emphasises the process of walking by means of long shots and takes. Meisie also transcends her marginal status. She finally attends school and her future seems brighter than that of the other female protagonists in Roodt's recent cinema.

\section{Conclusion}

These films display Roodt's cinematic humanism in his representation of (black) women on the edge of postapartheid society, which do get a voice in his work. At the same time, his deviation from the Hollywood classical narrative structure, for example, using the conventions of the Western in Jobman, has resulted in fascinating experimentation with form: neorealism and oral narrative structures in the case of Meisie and partly in Yesterday, cinéma vérité and neorealism in Zimbabwe and the silent film with avant-garde elements (especially the experimentation with sound) in Faith's Corner. Roodt's representation of marginalised characters, however, will also be subjected to criticism.

Despite recent successes in post-apartheid South African cinema, the economic viability, cultural diversity as well as gender and racial inequality of the film industry remains a site of public concern (Treffry-Goatley 2010). At the 2009 National Film and Video Foundation (NFVF) Film Industry Meeting, Clarence Hamilton, Head of Production and Development at the NFVF, presented statistics on South African film production since 1994. A total of 615 documentaries were made from 1994 to 2008, with 2003 and 2004 as the most prolific years (154 productions). White directors still dominate production at $68 \%$ compared to black directors at $32 \%$. Male directors constituted the highest percentage at $61 \%$ compared to females at $39 \%$. With regard to feature film production the NFVF research department estimated that from 1994 to 2008132 films were made. Representation of black directors is quite low at only $15 \%$, compared to white directors at $85 \%$. Representation of female directors is also quite low at only $18 \%$, compared to male directors at $82 \%$. Thanks largely to the legacies of apartheid, the already high barriers to entry into the South African film industry are considerably higher for people of colour in South Africa. For this and other reasons, black South Africans (including the female protagonists of Roodt's cinema) remain more often the subjects of features and documentaries than their makers.

Overcoming this barrier must be a long-term priority, as it is the only means by which an equitable plurality of voices may reach South African audiences (Botha 2012). This persistence of racial inequity has fuelled tensions throughout the South African film industry. In particular, white film-makers who seek to document black subjects face mounting criticism, regardless of the purity of their intentions or methods. Roodt is no exception.

[All photographs courtesy of Videovision.]

\section{References}

\section{References}

Armes, R. Dictionary of African filmmakers. Bloomington, Indiana University Press, 2008.

Blignaut, J. \& Botha, M. P. (eds.) Movies Moguls Mavericks: South African cinema 1979-1991. Cape Town, Showdata, 1992.

Botha, M. P. 'Women on the margin of South African society: Themes in the Cinema of Darrell James Roodt'. Kinema 35: (Spring 2011): pp. 29-40.

Botha, M. P. South African cinema 1896-2010. Bristol, Intellect Publishers, 2012.

Botha, M. P. \& Van Aswegen, A. Images of South Africa: The rise of the alternative film.Pretoria, 


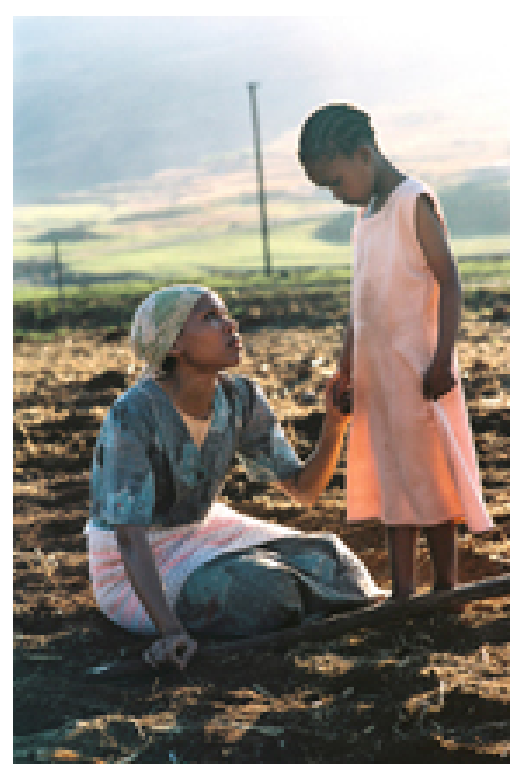

Figure 4: Leleti Khumalo and Lihle Mvelase in Yesterday

Human Sciences Research Council, 1992.

Horne, F. J. 'Yesterday, AIDS and structural violence in South Africa'. Communicatio 31:2 (2005): pp. $172-198$.

Maingard, J. South African national cinema. London, Routledge, 2007.

Murphy, D. \& Williams, P. Postcolonial African cinema: Ten directors. Manchester, Manchester University Press, 2007.

Ozynski, J. (ed.) Film: What the censors think. Johannesburg, Anti-Censorship Group, 1989.

Pichaske, K. Colour Adjustment: Race and Representation in Post-Apartheid South African Documentary. Unpublished PhD thesis, University of Cape Town, 2009.

Saks, L. Cinema in a democratic South Africa: The race for representation. Bloomington, Indiana, Indiana University Press, 2010.

Tomaselli, K. G. The cinema of apartheid: Race and class in South African film. London, Routledge, 1989.

Tomaselli, K. G. \& Prinsloo, J. Third cinema in South Africa, in J. Blignaut \& M. P. Botha (eds.)Movies Moguls Mavericks: South African cinema 1979-1991, (Cape Town, Showdata, 1992), pp. 329-373

Treffry-Goatley, A. The representation and mediation of a national identity in the production of post-apartheid South African cinema. Unpublished PhD thesis, University of Cape Town, 2010.

\section{Selected Filmography}

1983

City of Blood (Darrell Roodt) 
1986

Place of Weeping (Darrell Roodt)

1987

Tenth of a Second (Darrell Roodt)

The Stick (Darrell Roodt)

1989

Jobman (Darrell Roodt)

1991

Sarafina! (Darrell Roodt)

1993

To the Death (Darrell Roodt)

Fatherhood (Darrell Roodt)

1994

Cry the Beloved Country (Darrell Roodt)

1996

Dangerous Ground (Darrell Roodt)

2000

The Second Skin (Darrell Roodt)

2001

Witness to a Kill (Darrell Roodt)

2003

Pavement (Darrell Roodt)

Sumuru (Darrell Roodt)

2004

Dracula 3000 (Darrell Roodt)

Yesterday (Darrell Roodt)

2005

Charlie Jade (Television series)

Number Ten (Darrell Roodt)

Faith's Corner (Darrell Roodt)

2006

Prey (Darrell Roodt)

2007

Cryptid (as Darrell Michael)

Meisie (Darrell Roodt)

2008

Ella Blue (Television series)

Lullaby (Darrell Roodt)

Zimbabwe (Darrell Roodt)

2010

Jakhalsdans (Darrell Roodt)

League of Glory (Television series)

2011

Winnie (Darrell Roodt) 
2012

Little One (Darrell Roodt)

Room 9 (Television series)

Stilte (Darrell Roodt)

Wild at Heart (Television series)

2013

Stealing Time (Darrell Roodt)

\section{Author Information}

Martin P. BOTHA is Associate Professor of Film and Media Studies at the University of Cape Town. He has published more than 200 articles, reports and papers on South African media, including six books on South African cinema. His most recent book is South African Cinema 1896-2010 (Bristol: Intellect, 2012). 